V

\section{VALPARAISO UNIVERSITY}

1320 South Chapel Drive, Valparaiso, IN, 46383, United States of America

Tel: (1) 2194645317

Fax: (1) 2194645496

Email: lillyfellows.program@valpo.edu

Website: www.lillyfellows.org

Valparaiso University was founded in 1859 by Methodists, with approx. 4,000 students from most states and more than 40 countries. The university, which is nearly 150 years old offers more than 70 fields of study.

\section{Lilly Postdoctoral Teaching Fellowship Program}

Subjects: Arts and humanities.

Purpose: To strengthen the quality of church-related institutions of higher learning for the 21st century.

Eligibility: Open to new scholar-teachers who have obtained a PhD and are interested in the relationship between Christianity and the academic vocation and are seriously considering a career at a churchrelated college or university.

Level of Study: Postgraduate, Teaching

Type: Fellowships

Value: $\$ 47,300$ plus standard benefits, a moving allowance, and an annual professional and travel allowance

Length of Study: 2 years

Frequency: Annual

Country of Study: United States of America

No. of awards offered: 3

Application Procedure: Applicants must submit a curriculum vitae, a graduate transcript, 2 letters of recommendation and an essay or personal statement.

Closing Date: January 10th

Additional Information: All queries should be directed to lillyfellows. program@valpo.edu. For further information contact The Selection Committee Lilly Fellows Program at the above address.

\section{VATICAN FILM LIBRARY}

Mellon Fellowship Program, Pius XII Memorial Library, Saint Louis University, 3650 Lindell Boulevard, St Louis, MO, 63108 3302, United States of America Tel: (1) 3149773090

Fax: (1) 3149773108 Email: vfl@slu.edu

Website: http://libraries.slu.edu/special_collections/vfl/ Contact: Mrs Barbara J Channell, Secretary

The Vatican Film Library at Saint Louis University in St Louis, Missouri, is a microfilm repository for the Vatican Library manuscripts housed in Rome and a research centre for medieval and Renaissance manuscripts studies in general. The research collections contain a wide range of primary source manuscript materials on microfilm, microfiche and in digital reproduction, in addition to slides and printed facsimile editions ranging in date from the 5th to the 19th centuries, and a large number of incunabula and early-printed books also on microfilm and microfiche. At the core of these collections are the microfilmed copies of approx. three-quarters of the Vatican Library's Greek, Latin and Western European vernacular manuscripts, as well as Hebrew, Ethiopic and Arabic manuscripts.

\section{Vatican Film Library Mellon Fellowship}

Subjects: Classical languages and literature, palaeography, scriptural and patristic studies, history, philosophy and sciences in the Middle ages and the Renaissance and early Romance literature. There are also opportunities for supported research in the history of music, manuscript illumination, mathematics and technology, theology, liturgy, Roman and canon law or political theory.

Purpose: To assist scholars wishing to conduct research in the manuscript collections in the Vatican Film Library at Saint Louis University.
Eligibility: Open to candidates who are at the postdoctoral level, or graduate students formally admitted to PhD candidacy and working on their dissertation.

Level of Study: Doctorate, Graduate, Postdoctorate, Postgraduate, Predoctorate, Research

Type: Fellowship

Value: The scholarship provides travel expenses and a living allowance of $\$ 2,250$ per month for 2-8 weeks

Length of Study: 2-8 weeks

Study Establishment: The Vatican Film Library

Country of Study: United States of America

Application Procedure: Applicants must write, in the first instance, to describe the topic of the planned research and to indicate the exact dates during which support is desired. A formal application should then be submitted, which should include a cover letter stating the title and proposed dates of research, a detailed statement of the project proposal of not more than two or three pages in length, a list of the manuscripts or other archival materials to be consulted, a selective bibliography of primary and secondary sources relating to the research topic and a curriculum vitae. Applications submitted by $\mathrm{PhD}$ candidates should also include a letter of recommendation from their advisor with reference to the applicant's palaeographical and language.

Closing Date: March 1st for research in June to August, June 1st for research in September to December and October 1st for research in January to May

\section{VERNE CATT MCDOWELL CORPORATION}

PO Box 1336, Albany, OR, 97321-0440, United States of America Tel: (1) 5419240976

Contact: Ms Nadine Wood, Business Manager

The Verne Catt McDowell Scholarship educates pastoral ministers of the Christian Church (Disciples of Christ) by providing supplementary financial grants to graduate theology students.

\section{Verne Catt McDowell Corporation Scholarship}

Subjects: Religion, theology and church administration.

Purpose: To provide supplemental financial grants to men and women for graduate theological education for ministry in the Christian Church (Disciples of Christ) denomination.

Eligibility: All scholarship candidates must be ministers ordained or studying to meet the requirements to be ordained as a minister in the Christian Church (Disciples of Christ). Candidates must be members of the Christian Church (Disciples of Christ) denomination. Preference is given to Oregon graduates and citizens of the US.

Level of Study: Postgraduate, Doctorate

Type: Scholarship

Value: Average: $\$ 3,000$

Length of Study: $1-3$ years

Study Establishment: A graduate institution of theological education, accredited by the general assembly of the Christian Church (Disciples of Christ)

Country of Study: United States of America

No. of awards offered: 5

Application Procedure: Applicants must complete an application form and provide details of qualifications, transcripts, 3 references and state where they obtained information about the scholarship. An interview may be requested.

Closing Date: May 1st

Funding: Private

Contributor: I A McDowell

No. of awards given last year: 3

No. of applicants last year: 4

\section{VERNON WILLEY TRUST-GUARDIAN TRUST COMPANY}

PO Box 9, Christchurch, 8001, New Zealand Tel: (64) 33790645

Fax: (64) 33667616

Email: gary anderson@nzgt.co.nz

Website: www.nzgt.co.nz

Contact: Mr G Anderson, Client Manager 


\section{Vernon Willey Trust Awards}

Subjects: The sheep and wool industry of New Zealand.

Purpose: To assist with research and education into the production, processing and marketing of wool and the general development of the industry for the national benefit of New Zealand.

Eligibility: Open to New Zealand citizens, permanent New Zealand residents or overseas researchers working in New Zealand.

Level of Study: Doctorate, Postdoctorate

Type: Fellowship

Value: Varies, usually between New Zealand $\$ 30,000$ to 35,000

Length of Study: Up to 3 years

Frequency: Dependent on funds available

Country of Study: New Zealand

No. of awards offered: 1

Application Procedure: Applicants must complete an application form.

Closing Date: March 31st

Funding: Private

No. of awards given last year: 3

No. of applicants last year: 6

Additional Information: Applicants for financial grants must satisfy the Committee that their activities are of general or public benefit. The results of the research or studies are expected to be covered by material suitable for publication in recognized scientific or technical journals.

\section{VICTORIA UNIVERSITY OF WELLINGTON}

PO Box 600 , Wellington, 6140 , New Zealand Tel: (64) 44635113,44721000

Fax: (64) 4496 5454, 44994601

Email: scholarships-office@vuw.ac.nz

Website: www.vuw.ac.nz

Contact: Scholarship Office

Victoria University of Wellington is New Zealand's most research intensive university, located in New Zealand's compact vibrant capital city. It is one of the oldest universities in New Zealand. Victoria has produced Nobel prize winning scholars and a Booker prize winner. Victoria provides excellent supervision, facilities and financial support for postgraduate research. Scholarships are available in all disciplines.

\section{Rachael Westergaard Memorial Masters Scholarship in Geophysics}

Subjects: Geophysics.

Purpose: The scholarship is to encourage students into the field of Geophysics, an area which Rachael was very passionate about. Eligibility: Eligible to nationals of New Zealand citizens or permanent residents, or Canadian citizens.

Level of Study: Postgraduate

Type: Scholarship

Value: $\$ 15,000$ stipend plus domestic tuition fees

Length of Study: 1 year

Frequency: Annual

No. of awards offered: 1

Application Procedure: Application forms and supporting documents should be sent to Scholarships Office.

Closing Date: November 1st

Additional Information: This scholarship has been established in memory of Rachael Westergaard, a student at Victoria from 2009 to 2012. The scholarship is to encourage students into the field of Geophysics. To recognize Rachael's dual citizenship, it is open to New Zealand citizens or permanent residents, or Canadian citizens.

\section{Victoria Doctoral Scholarships}

Subjects: All subjects.

Purpose: To provide financial assistance to Doctoral students. Eligibility: Open to students who are about to commence their Doctoral studies. The selection is based on academic merit.
Level of Study: Doctorate, Postgraduate

Type: Scholarship

Value: New Zealand $\$ 23,500$ stipend annually, plus tuition fees Length of Study: 3 years

Study Establishment: Victoria University of Wellington

Country of Study: New Zealand

Application Procedure: Online applications available at www. victoria.ac.nz/fgr.

Closing Date: Victoria PhD scholarships - March 1st, July 1st, and November 1st

Contributor: Victoria University of Wellington

No. of awards given last year: 120

No. of applicants last year: 1,000

Additional Information: Application for PhD scholarships and admission to the university is one process. Email at pg-research@vuw.ac.nz for more information. A number of other scholarships are available and a complete listing can be found at www.vuw.ac.nz/scholarships.

\section{VILLA I TATTI: THE HARVARD UNIVERSITY CENTER FOR ITALIAN RENAISSANCE STUDIES}

Via di Vincigliata 22, 50135 Florence, Florence, Italy Tel: (39) 055603251

Fax: (39) 055603383

Email: info@itatti.harvard.edu

Website: www.itatti.harvard.edu

Contact: Angela Lees, Administrative Assistant

Villa I Tatti is devoted to advanced study of the Italian Renaissance in all its aspects, the history of art, political, economic and social history, the history of science, philosophy and religion and the history of literature and music.

\section{Berenson Fellowship}

Subjects: Fellowship to work at I Tatti for 4 or 6 months. The Fellowship is designed for scholars who explore 'Italy in the World'. Projects should address the transnational dialogues between Italy and other cultures (e.g. Latin American, Mediterranean, African, Asian etc.) during the Renaissance, broadly understood historically to include the period from the 14th to the 17th century.

Purpose: Advanced research in the Italian Renaissance.

Eligibility: Applicants must be conversant in English and have familiarity with Italian. At the time of application, a $\mathrm{PhD}$ is required. Priority will be given to early and mid-career scholars. Projects can address any aspect of the Renaissance, including art and architecture landscape architecture, history, literature, material culture, music, philosophy, religion, and science. It must be possible for applicants to carry out most of their research in Florence. I Tatti welcomes applications from scholars from all nations and gives special consideration to candidates without regular access to research materials and facilities in Italy.

Level of Study: Postdoctorate

Type: Residential fellowships

Value: Up to $\$ 4,000$ per month plus a one-time supplement (Max: 1,500)

Length of Study: 4 to 6 months

Frequency: Annual

Country of Study: Italy

No. of awards offered: Up to 4

Application Procedure: Please check at http://itatti.harvard.edu/ craig-hugh-smyth-visiting-fellowship.

Closing Date: December 14th

Funding: Foundation

Contributor: The Lila Wallace - Reader's Digest Fund

\section{Craig Hugh Smyth Fellowship}

Subjects: Fellowship to work at I Tatti for 4 to 6 months. The Fellowship is designed for scholars who work for an educational or cultural institution as a curator or conservator. The project must represent advanced research in any aspect of the Italian Renaissance 
and applicants may apply to carry out research on behalf of their home institution, or propose projects relating to their personal research interests.

Purpose: Advanced research in the Italian Renaissance.

Eligibility: Italian Renaissance scholars with limited research time, see website.

Level of Study: Doctorate, Postdoctorate, Predoctorate

Type: Residential fellowships

Value: Up to $\$ 4,000$ per month plus a one-time supplement (Max. $\$ 1,500$ ) towards relocation expenses. (If an apartment is not avaliable $\$ 1,000$ per month will be offered to help offset rental costs.)

Length of Study: 4 or 6 months

Frequency: Annual

Country of Study: Italy

No. of awards offered: 2

Application Procedure: Please check at http://itatti.harvard.edu/ craig-hugh-smyth-visiting-fellowship

Closing Date: December 14th

Funding: Foundation

Contributor: The Andrew W. Mellon Foundation

\section{David and Julie Tobey Fellowships}

Subjects: Fellowship to work at I Tatti for 3 months. This fellowship supports research on drawings, prints, and illustrated manuscripts from the Italian Renaissance, and especially the role that these works played in the creative process, the history of taste and collecting, and questions of connoisseurship. Proposals on a variety of subjects with a substantive component of research on drawings, prints, and illustrated manuscripts done on paper or parchment types are welcome.

Level of Study: Postdoctorate

Type: Residential fellowships

Value: Up to $\$ 4,000$ per month plus a one-time supplement (Max: 1,500)

Length of Study: 3 months

Frequency: Annual

Country of Study: Italy

No. of awards offered: Up to 1

Application Procedure: Please check at http://itatti.harvard.edu/ david-and-julie-tobey-fellowship.

Closing Date: December 14th

Funding: Foundation

Contributor: The Lila Wallace - Reader's Digest Fund

\section{Tatti Fellowships}

Subjects: Fellowship to work at I Tatti for 1 year. The project must represent advanced research in the Italian Renaissance broadly understood historically to include the period from the 14th to the 17th century and geographically to include transnational dialogues between Italy and other cultures (e.g. Latin American, Mediterranean, African, Asian, etc.). Subjects covered include art and architecture, history, literature, material culture, music, philosophy, religion, and science. Scholars can also apply to work on the transmission and circulation of ideas, objects, and people during the Renaissance, into and beyond the Italian peninsula, or on the historiography of the Italian

Renaissance, including the rebirth of interest in the Renaissance in later periods.

Purpose: Advanced research in the Italian Renaissance.

Eligibility: At the time of application, scholars must hold a PhD, dottorato di ricerca, or an equivalent doctorate. They must be conversant in either English or Italian and able to understand both languages. They should be in the early stages of their career, having received a $\mathrm{PhD}$ and have a solid background in Italian Renaissance studies.

Level of Study: Postdoctorate

Type: Residential fellowships

Value: US $\$ 50,000$

Length of Study: 1 year

Frequency: Annual

Country of Study: Italy

No. of awards offered: 15

Application Procedure: Please check at http://itatti.harvard.edu/ i-tatti-fellowship
Closing Date: October 15th

Funding: Foundation, individuals, private, trusts

No. of awards given last year: 15

\section{Mellon Fellowship in Digital Humanities}

Subjects: Fellowship to work at I Tatti for 4 or 6 months. The Fellowship is designed to support the work of scholars in the humanities or social sciences, librarians, archivists, and data science professionals whose research interests or practice cut across traditional disciplinary boundaries and actively employ technology in their work. Projects can address any aspect of the Italian Renaissance, broadly understood historically to include the period from the 14th to the 17th century, and geographically to include transnational dialogues between Italy and other cultures (e.g. Latin American, Mediterranean, African, Asian etc.). Projects should apply digital technologies such as mapping, textual analysis, visualization, or the semantic web to topics in fields such as art and architecture, history, literature, material culture, music, philosophy, religion, and history of science.

Eligibility: A PhD is required for scholars in the humanities and social sciences; in exceptional cases, applications from advanced PhD (ABD) students will be considered. A Master's degree is required for librarians, archivists, and data science professionals. A background in programming, library sciences, computer graphics, computational linguistics, or other fields relevant to digital humanities research is highly desirable. Candidates should possess the technical skills to carry out their project at the time of application.

Level of Study: Postdoctorate and Predoctorate

Type: Residential fellowships

Value: Up to $\$ 4,000$ per month plus a one-time supplement

(Max: 1,500)

Length of Study: 4 to 6 months

Frequency: Annual

Country of Study: Italy

No. of awards offered: Up to 2

Application Procedure: Please check at http://itatti.harvard.edu/ mellon-fellowship-digital-humanities.

Closing Date: December 14th

Funding: Foundation

Contributor: Andrew W. Mellon Foundation

\section{Wallace Fellowship}

Subjects: Fellowship to work at I Tatti for 4 or 6 months. The Fellowship is designed for scholars who explore the historiography and impact of the Italian Renaissance in the Modern Era (19th-21st centuries). Projects could address a range of topics from historiography to the reaction to, transformation of, and commentary on the Italian Renaissance and its ties to modernity. Also welcome are projects on museum and collecting history, and on the survival of the Renaissance in modern art and architecture (including photography and landscape architecture), in literature and music, and in philosophy and political thought. Eligibility: Applicants must be conversant in English and have familiarity with Italian. At the time of application, a PhD is required. Priority will be given to early and mid-career scholars. Projects can address the historiography or impact of the Renaissance on any field, including art and architecture, landscape architecture, history,

literature, material culture, music, philosophy, religion, and science. It must be possible for applicants to carry out most of their research in Florence. I Tatti welcomes applications from scholars from all nations and gives special consideration to candidates without regular access to research materials and facilities in Italy.

Level of Study: Postdoctorate

Type: Residential fellowships

Value: Up to $\$ 4,000$ per month plus a one-time supplement

(Max: 1,500)

Length of Study: 4 to 6 months

Frequency: Annual

Country of Study: Italy

No. of awards offered: Up to 4

Application Procedure: Please check at http://itatti.harvard.edu/ wallace-fellowship.

Closing Date: December 14th

Funding: Foundation

Contributor: The Lila Wallace - Reader's Digest Fund 


\section{THE VINAVER TRUST}

45 Albert Street, Western Hill, Durham, DH1 4RJ, England Tel: (44) 01913868898

Email: geoffreybromiley@btinternet.com

Contact: Dr G.N. Bromiley, Secretary-Treasurer

The Eugène Vinaver Memorial Trust exists to promote research into Arthurian studies, as defined by the International Arthurian Society. It offers subventions to publishers to facilitate the publication of scholarly works; it also offers grants to postgraduate students pursuing research in the Arthurian field.

\section{Barron Bequest}

Subjects: Any field of Arthurian studies.

Purpose: To support postgraduate research in Arthurian studies. Eligibility: Open to graduates of any university of the United Kingdom or the Republic of Ireland.

Level of Study: Postgraduate Research

Type: Grant

Value: Up to UK£1,250 towards academic fees

Length of Study: 1 year. Candidates may apply for further years on a basis of parity with those applying for the first time

Frequency: Annual

Country of Study: United Kingdom, Republic of Ireland

No. of awards offered: Varies

Application Procedure: For application details applicants must contact Professor J.H.M. Taylor at the address given below.

Closing Date: April 30th

Funding: Private

Contributor: The Eugène Vinaver Memorial Trust

No. of awards given last year: 1

No. of applicants last year: 2

For further information contact:

Penruddock, Penrith, Cumbria, CA11 0QU, United Kingdom

Email: jane.taylor@durham.ac.uk

Contact: Professor Jane H M Taylor, Garth Head

\section{VISUAL COMMUNICATIONS (VC)}

120 Judge John Aiso Street, Basement Level, Los Angeles, CA, 90012-3805, United States of America

Tel: (1) 2136804462

Fax: (1) 2136874848

Email: kennedy@vconline.org

Website: www.vconline.org

Contact: Kennedy Kabasares

Visual Communications (VC) is the premier Asian Pacific media arts center in the United States of America with a history of more than 30 years. It promotes intercultural understanding through the production, presentation and preservation of honest and sensitive stories about Asian Pacific people.

\section{Armed with a Camera Fellowship}

\section{Subjects: Photography.}

Purpose: To cultivate a new generation of Asian Pacific American media artists committed to preserving the legacy and vision of $\mathrm{VC}$. Eligibility: Open to candidates of Asian Pacific descent, who are 30 years of age or below, and are residents of California and have had previous work experience in the VC Film fest, Chili visions, any other VC exhibition and/or any film festival.

Level of Study: Professional development

Type: Fellowships

Value: $\$ 1,000$ in cash and $\$ 1,000$ in equipment rental to complete a four to five-minute digital video

Length of Study: 7 months

Frequency: Annual

No. of awards offered: 10

Closing Date: October 17th

Additional Information: Please check at www.vconline.org/alpha/ cms/index.cfm/programs/artist-services/armed-with-a-camerafellowship/ for further information.

\section{VLIR-UOS}

VLIR-UOS, Postbus 103 Elsene Naamsepoort, Elsene, BEL, 1050, Belgium Tel: (32) 22890550

Email: info@vliruos.be

Website: www.vliruos.be/en/

VLIR-UOS primarily supports partnerships between universities and university colleges. VLIR-UOS also builds bridges between higher education on the one hand and governments, NGOs and businesses in Flanders and the South on the other.

\section{VLIR-UOS Scholarships for International Master Programme (ICP)}

Subjects: With the International Master Programme (ICP) VLIR-UOS supports a selected number of accredited (initial or comlementary) Master programmes of 2, 3 or 4 semesters on a subject that is deemed relevant to or specific for development.

Eligibility: A candidate should be a national and resident of one of the countries of the VLIR-UOS country list for scholarships (not necessarily the same country) at the time of application. The maximum age for a ICP candidate is 35 years for an initial masters and 40 years for an advanced masters. The candidate cannot exceed this age on January 1 of the intake year

Level of Study: Postgraduate

Value: $€ 150,000$ (for 2-year/4 semesters/120 credits Master programmes); $€ 125,000$ (for 1.5 -year/3 semesters/90 credits Master programmes); $€ 100,000$ (for 1 -year/2 semesters/60 credits Master programmes); per year for a 5 -year period

Length of Study: Selection is valid for a 5-year period, with possible renewal for another 5-year term

Frequency: Selection is valid for a five-year period Country of Study: Belgium

No. of awards offered: 12 awards

Closing Date: This deadline is different for the different university associations

Funding: International Office

\section{THE VOLKSWAGEN FOUNDATION}

Kastanienallee 35, 30519 Hannover, Germany

Tel: (49) 051183810

Fax: (49) 05118381344

Email: info(at)volkswagenstiftung.de

Contact: VolkswagenStiftung

The Volkswagen Foundation (VolkswagenStiftung) is dedicated to the support of the humanities and social sciences as well as science and technology in higher education and research. It funds research projects in path-breaking areas and provides assistance to academic institutions for the improvement of the structural conditions for their work. In particular, the Foundation perceives its mission in supporting aspiring young researchers and in promoting interdisciplinary and international collaboration.

\section{Volkswagen Foundation Freigeist Fellowships}

Subjects: Open to all disciplines and topics.

Purpose: The Freigeist funding initiative aims to encourage exceptional research personalities to embark on visionary, risk-taking research projects at the intersections between established field of research.

Eligibility: Anyone can apply who identifies with the goals of a "Freigeist" Fellowship and whose proposed research projects fits in with the aims pursued by the Freigeist initiative.

Level of Study: Doctorate, Postdoctorate

Value: $€ 1,000,000$

Frequency: Annual

Country of Study: Germany

No. of awards offered: 10 to 15 per year

Application Procedure: Applications can be submitted online via the Electronic Application System of the Volkswagen Foundation.

Instructions are found online.

Closing Date: October 12th 


\section{VSB FOUNDATION}

34 Shaftesbury Square, Belfast, BT2 7DB, Northern Ireland

Tel: (44) 90200850

Fax: (44) 90200860

Website: www.vsb.org.uk

The VSB Foundation was created in 2005 with the following objects like change, facilitate and improve the active participation by groups and individuals who tend to be underrepresented in public decision making processes, particularly older people, young people and ethnic minorities and much more.

\section{Pilgrim Trust-VSB Foundation Small Grants \\ Programme}

Purpose: To encourage local community interventions to address some of the underlying causes that contribute to women's offending and/or offer practical support to those women caught in the criminal justice system to prevent re-offending.

Eligibility: Consideration will be given to projects that are making connections or engaging with key organizations, both statutory and/or voluntary, working within the criminal justice system, health service or housing sector. Consideration will be given to local community based organizations that seek to build their capacity, expertise and engagement with this area of work. A particular interest is to support initiatives working with women offenders in rural towns.

Type: Scholarship

Value: This is a small grants programme the maximum award will be in the region of $£ 2,000-5,000$

Application Procedure: Applicants should submit a 2-4 page application that outlines and evidences the rationale for the project or intervention. This should include a proposed project budget, the status of the group/organization and recent set of accounts. Applications should be submitted to: Bill Osborne, VSB, 34 Shaftesbury Square, Belfast BT2 7DB; Tel: 0289020 0852; Email: bill@vsb.org.uk.

Closing Date: There is no set closing date but early application is advisable as funding is limited

Additional Information: For detailed information, please visit www.vsb.org.uk/funding/item/2/pligrim-trust-vsb-foundation-smallgrants-programme/. 